\title{
Impatiens wutaishanensis (Balsaminaceae), a new species from Southeast Yunnan, China
}

\author{
Rong-Li Liao ${ }^{1,2,3^{*}}$, Lei Cai ${ }^{*}$, Zhi-Yong Yu ${ }^{4}$, Yue-Hua Wang', Wei-Bang Sun ${ }^{2}$ \\ I School of Life Sciences, Yunnan University, Kunming 650091, Yunnan, China 2 Yunnan Key Laboratory \\ for Integrative Conservation of Plant Species with Extremely Small Populations / Key Laboratory for Plant \\ Diversity and Biogeography of East Asia, Kunming Institute of Botany, Chinese Academy of Sciences, Kunming \\ 650201, Yunnan, China 3 University of Chinese Academy of Sciences, Beijing 100049, China 4 Management \\ Bureau of Jinping Fenshuiling National Nature Reserve, Jingping 661500, Yunnan, China \\ Corresponding author: Yue-Hua Wang (wangyh58212@126.com); Wei-Bang Sun (wbsun@mail.kib.ac.cn)
}

Academic editor: S. Knapp | Received 20 September 2020 | Accepted 6 March 2021 | Published 16 April 2021

Citation: Liao R-L, Cai L, Yu Z-Y, Wang Y-H, Sun W-B (2021) Impatiens wutaishanensis (Balsaminaceae), a new species from Southeast Yunnan, China. PhytoKeys 176: 43-53. https://doi.org/10.3897/phytokeys.176.58825

\begin{abstract}
Impatiens wutaishanensis R.L. Liao \& Lei Cai, a new species from Southeast Yunnan, China, is here described and illustrated. This new species is most similar to Impatiens parvisepala S.X. Yu \& Y.T. Hou in its racemose inflorescences, its four lateral sepals, the leaf arrangement, and in having yellow flowers. However, it differs in the height of the plants, the length of the petiole, the size and shape of the leaf blade, the shape of the spur, and the number of flowers in each inflorescence. A detailed description, color photographs, and a provisional IUCN red list assessment are provided, and its geographical distribution, ecology, and morphological relationship with relevant similar species are discussed.
\end{abstract}

\section{Keywords}

China, Flora of Yunnan, Impatiens parvisepala, Impatiens wutaishanensis, morphology

\section{Introduction}

The genus Impatiens Linnaeus (1753: 937) belongs to the family Balsaminaceae, and has a mainly Old World tropical and subtropical distribution, although a few species are found in the northern temperate regions of Europe, Russia and China

\footnotetext{
* This author contributed equally as the first author.
}

Copyright Rong-Li Liao et al.. This is an open access article distributed under the terms of the Creative Commons Attribution License (CC BY 4.0), which permits unrestricted use, distribution, and reproduction in any medium, provided the original author and source are credited. 
as well as North America. There are over 1000 species known to the genus to date (Grey-Wilson 1980; Fischer 2004). Major biodiversity hotspots for Impatiens species include tropical Africa, Madagascar, southern India and Sri Lanka, eastern Himalayas, and Southeast Asia (Song et al. 2003; Yuan et al. 2004). In China, more than 270 species of Impatiens are recorded, of which over 240 are endemic to the country. Southwest China is, in the broad sense, part of the Southeast Asian area, and belongs to one of the biodiversity hotspots of the genus Impatiens with more than 200 species (Yuan et al. 2004; Xia et al. 2019a; Peng et al. 2020). The Chinese Impatiens species are mainly found in Southwest China's Yunnan, Sichuan, Tibet, Guangxi and Guizhou Provinces (Chen 2001; Chen et al. 2007; Yu 2012; Zhang et al. 2013). In recent years, about 30 new species of Impatiens have been described from China, and a large proportion of these are found in Southwest China (e.g. Hou et al. 2011; Cai et al. 2015; Tan et al. 2015; Guo et al. 2016; Ding et al. 2016; Xia et al. 2019a, b; Lu et al. 2020). In 2015, during a botanical investigation in Jinping County, Southwest Yunnan Province, China, we collected some specimens of an unknown Impatiens species. After careful examination of the relevant specimens and literature of the genus Impatiens within the adjacent regions (Chen 2001; Chen et al. 2007; Hou et al. 2011; Shui et al. 2011; Yu 2012; Cai et al. 2015; Tan et al. 2015; Chinh et al.2015; Xia et al. 2019b), we concluded that the Impatiens species differed from previously reported or described taxa, and which we describe it here as a new species.

\section{Materials and methods}

The material for this study was mainly collected during field surveys assessing the conservation status of the plants of Yunnan Province, China. Herbarium specimens were made carefully and dissected flowers were dried separately to enable examination and illustration in the laboratory. Additionally, flowers were preserved in formalin-acetic acid-alcohol (FAA) solution, and field notes were taken. The morphological characteristics of the new species were measured using a ruler and vernier calipers from both dried herbarium specimens and mature individuals of living plants in the field. Morphological features of the flowers were described and measured using a dissecting microscope.

Fresh pollen grains and leaf blades were collected from the living plants introduced from the field and cultivated at Kunming Botanical Garden (KBG) and loaded on the cryo-specimen holder and cryo-fixed in slush nitrogen $\left(-210{ }^{\circ} \mathrm{C}\right)$, then sublimed and sputter-coated with $\mathrm{Pt}$ in a vacuum scanning electron microscopy (SEM) chamber at $-140{ }^{\circ} \mathrm{C}$. Morphological characters were observed, examined, and photographed with a cryo-SEM. The morphology of 30 pollen grains was measured and described according to terminology of pollen grains (Lu 1991; Janssens et al. 2012). 


\section{Taxonomic treatment}

\section{Impatiens wutaishanensis R.L. Liao \& Lei Cai, sp. nov.} urn:Isid:ipni.org:names:77216566-1

Figs 1, 2

Type. China, Yunnan Province, Jinping County, Maandi, alt. $1650 \mathrm{~m}$ a.s.l., 2246'19.97"N, 10328'29.78"E, 10 September 2016, Lei Cai \& Z.Y. Yu CL16050 (holotype:1498854, KUN!; isotypes:1498855, KUN!).

Diagnosis. This species is similar to Impatiens parvisepala S.X. Yu \& Y.T. Hou (2011: 57) (Hou et al. 2011) in its racemose inflorescences, its alternate and aggregated or subverticillate at stem apex arrangement leaf, and its yellow flowers, but it can be distinguished by its conspicuous $0.5-2.4 \mathrm{~cm}$ long petiole (vs. sub-sessile or sessile), its shorter 10-35 cm high plants (vs. 35-60 cm high), its 3.5-12 × 1.5-4 cm elliptic to lanceolate-oblong leaf blades with cuneate bases (vs. 12-20 × 3.5-6 cm obovate or obovate-lanceolate blade with attenuate bases), its slightly incurved or narrowing to incurved spur (vs. nearly straight spur), and its racemose inflorescences with up to 22 flowers (vs. 6-8 flowers per inflorescence).

Description. Perennial herb, $10-35 \mathrm{~cm}$ tall, glabrous. Root-system shallow, with runners and adventitious roots. Stem fleshy, erect, simple, lower nodes swollen. Leaves simple, alternate, aggregated or subverticillate at stem apex; petiole $0.5-2.4 \mathrm{~cm}$ long, leaf blade 3.5-12 × 1.5-4 cm, elliptic, lanceolate, or lanceolate-oblong, base cuneate, margin roughly crenate, mucronulate, apex acuminate, adaxial surface dark green, abaxial surface pale green, lateral veins 4-8 pairs. Racemes in the upper leaf axils, 1-4, $4.2-28 \mathrm{~cm}$ long, erect, each with up to 22 flowers. Pedicels $0.6-2.5 \mathrm{~cm}$ long, bracteate at base. Bracts ca. $8 \mathrm{~mm}$ long, lanceolate to subulate, apex acute, base obtuse, margin entire. Flowers yellow. Lateral sepals 4, light green, the outer pair ca. 5-8 × 3-4 mm, ovate or obovate; the inner pair ca. $8-13 \times 1-3 \mathrm{~mm}$, sickle-shaped, obliquely lanceolate, apex acuminate or caudate. Lower sepal $1.5-2.2 \times 1.2-2 \mathrm{~cm}$ excluding the spur, yellow to yellowish green with reddish patches, obliquely infundibuliform, base gradually constricted into a spur, spur $1.2-3 \mathrm{~cm}$ long, slightly incurved or narrowing to incurved, apex rostellate. Dorsal petal $1.3-2.3 \times 0.7-1.6 \mathrm{~cm}$, yellow with nearly transparent base, obovate to ovate, apex acuminate, with an inconspicuous dorsal crest, base truncate or cuneate. Lateral united petals ca. 1.6-3 cm long, yellow with nearly transparent base and reddish patches; the upper petals ca. 1.5-2.3 $\times 0.7-1 \mathrm{~cm}$, oblong; the lower petal ca.1.2-1.8 $\times 0.6-0.8 \mathrm{~cm}$, reniform. Stamens 5, filaments linear, ca. 3 $\mathrm{mm}$ long, anthers obtuse. Ovary fusiform, slightly curved. Placentation axile with four locules. Capsule (immature) clavate, $2-2.5 \mathrm{~cm}$ long.

Pollen morphology. Pollen grains triangular-round with three equal sides in polar view, and the equatorial view is elliptic, long-elliptic, $\mathrm{P} \times \mathrm{E}=16.56 \pm 1.78$ (14.51$21.73) \times 30.00 \pm 0.98(28.35-32.11) \mu \mathrm{m}$. 3-colpate, linear, the entire surface is covered with reticulate ornamentation, granules in lumina (Fig. 3). 

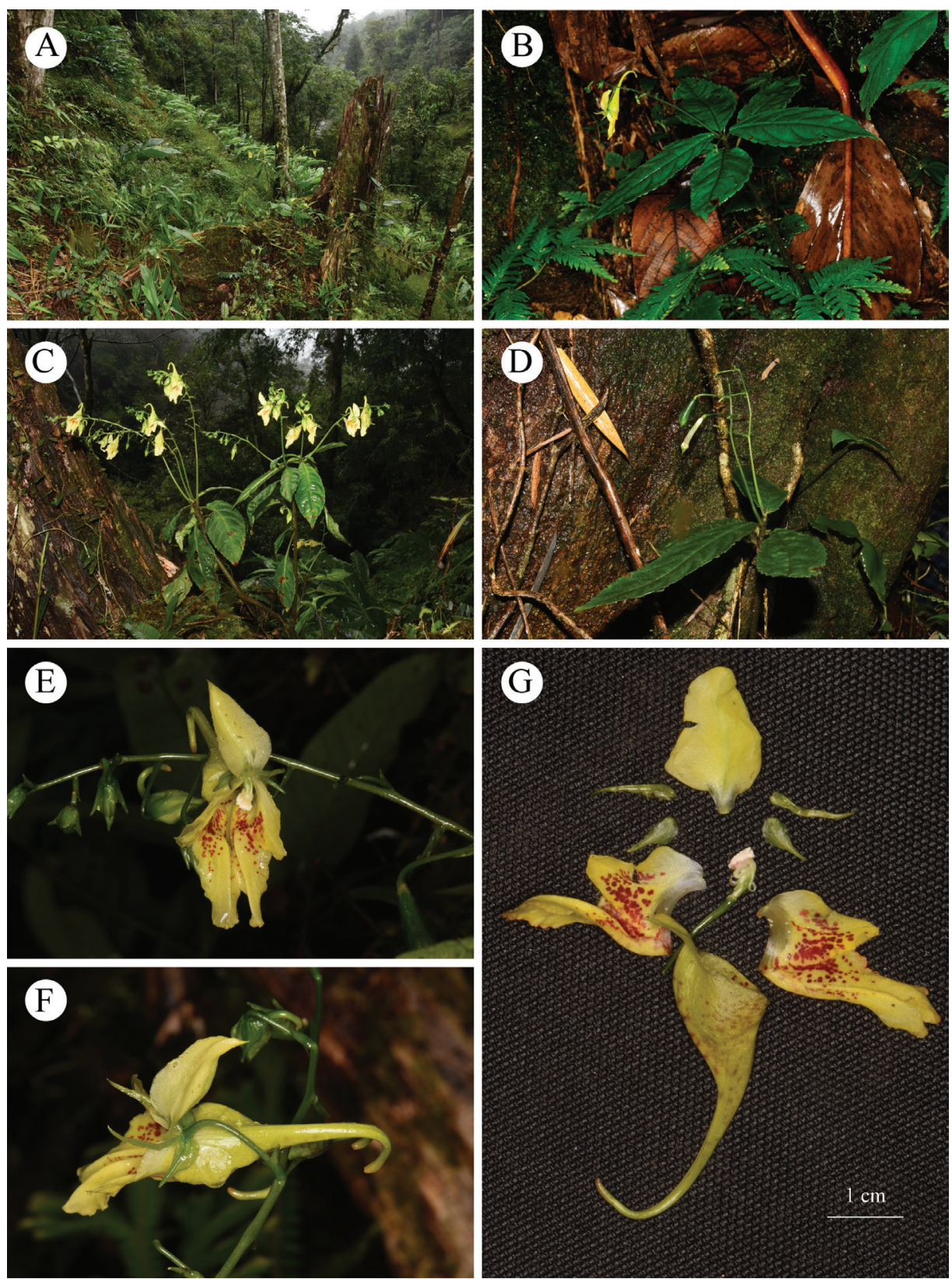

Figure I. Impatiens wutaishanensis R.L. Liao \& Lei Cai A habit B whole plant $\mathbf{C}$ inflorescence $\mathbf{D}$ capsule $\mathbf{E}$ flower in front view $\mathbf{F}$ flower in lateral view $\mathbf{G}$ different parts of the flower.

Leaf surface micromorphology. The anticlinal walls of the epidermal cells on the adaxial surfaces are straight, while those of the abaxial surface are sinuate. The stomata only appeared on the abaxial surface of the leaf, the shape was anomocytic and the outline of the guard cells was suborbiculate (Fig. 3). 


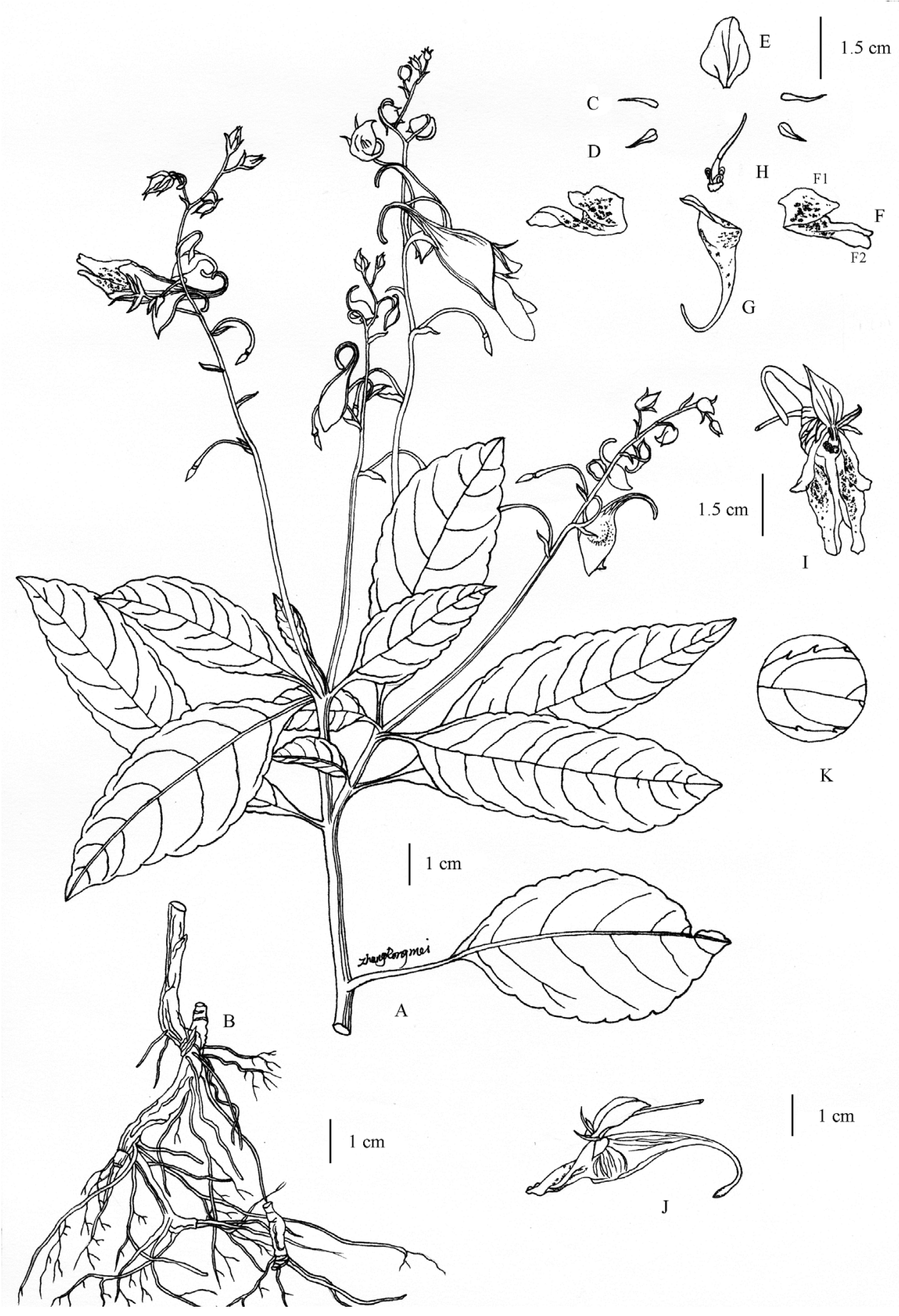

Figure 2. Impatiens wutaishanensis R.L. Liao \& Lei Cai (drawn by R.M. Zhang) A habit B root $\mathbf{C}$ inner lateral sepal $\mathbf{D}$ outer lateral sepal $\mathbf{E}$ dorsal petal $\mathbf{F}$ lateral united petals (F1: upper petal F2: lower petal) $\mathbf{G}$ lower sepal $\mathbf{H}$ ovary and stamens $\mathbf{I}$ flower in front view $\mathbf{J}$ flower in lateral view $\mathbf{K}$ partial view of leaf margin. 

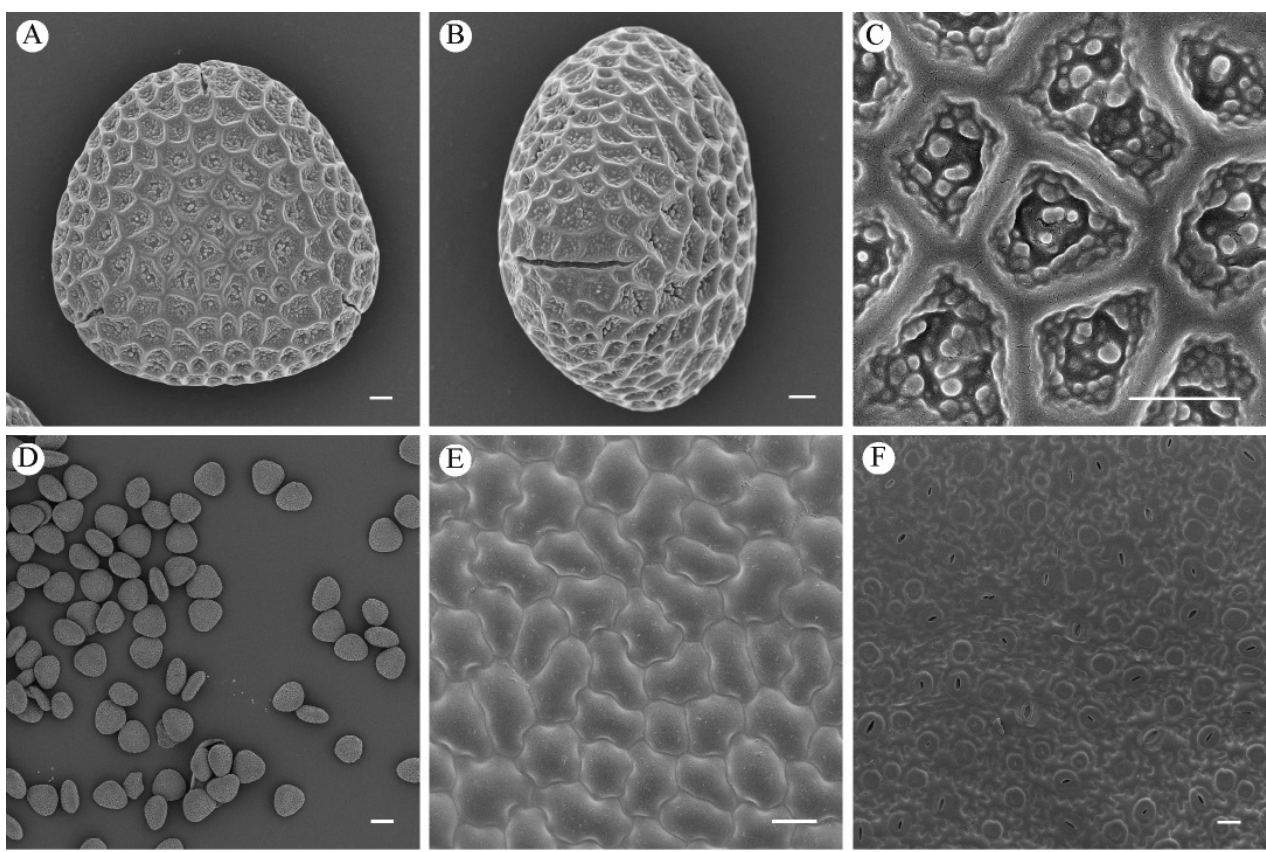

Figure 3. Micromorphology of Impatiens wutaishanensis R.L. Liao \& Lei Cai under cryo-SEM A-D pollen $\mathbf{A}$ polar view $\mathbf{B}$ equatorial view $\mathbf{C}$ partial view $\mathbf{D}$ total view $\mathbf{E}-\mathbf{F}$ leaf surface $\mathbf{E}$ adaxial epidermis $\mathbf{F}$ abaxial epidermis. Scale bar: $2 \mu \mathrm{m}(\mathbf{A}, \mathbf{B}) ; 1 \mu \mathrm{m}(\mathbf{C}) ; 20 \mu \mathrm{m}(\mathbf{D}-\mathbf{F})$.

Phenology. This new species was observed flowering from August to November, and fruiting from September to December.

Distribution. This species is currently known from only two small subpopulations less than $10 \mathrm{~km}$ away (Shidong and Biaoshuiyan) in Jinping County of Southeast Yunnan, China (Fig. 4). The distribution area is very close to the border between China and Vietnam. We assume that this species should be distributed in Vietnam due to its similar habitat and proximity to the type locality, which will be verified by future investigation.

Ecology. This new species has a runner with adventitious root produced from the nodes and was collected growing in the understory of forest at an elevation of 1300-1650 m. In the subpopulation in Shidong, the plants found coexist with the cultivated Amomum tsaoko Crevost \& Lemarie (Zingiberaceae). In the subpopulation in Biaoshuiyan, the plants were found beside the artificial trail in a scenic area. The main accompanying species were Begonia Linn. sp. (Begoniaceae), Didymocarpus purpureobracteatus W.W. Smith (Gesneriaceae), Epigeneium amplum (Lindl.) Summerh. (Orchidaceae), Hedychium villosum Wall. (Zingiberaceae), Polygala fallax Hemsl. (Polygalaceae) and Vaccinium Linn. sp. (Ericaceae).

Conservation status. This species is currently known only from Jinping County, Yunnan, China with one type locality and a subpopulation. The Extent of Occurrence (EOO) is less than $100 \mathrm{~km}^{2}$ and the known Area of Occupancy (AOO) is less than 15 $\mathrm{km}^{2}$. The conservation status can be evaluated as Vulnerable (VU) D2 based on IUCN 


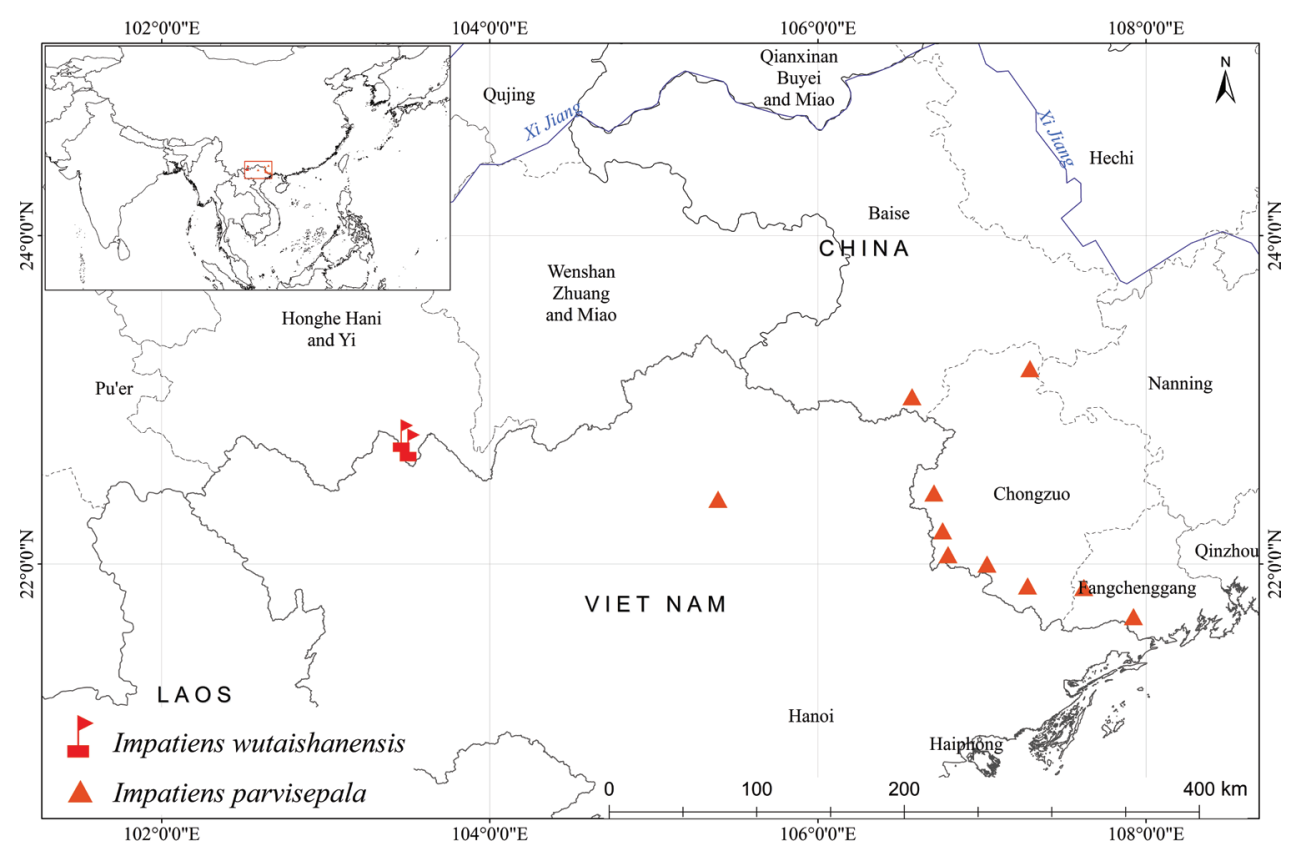

Figure 4. Distribution of Impatiens wutaishanensis R.L. Liao \& Lei Cai and I. parvisepala S.X. Yu \& Y.T. Hou.

Red List Categories and Criteria (IUCN 2019). About 350 and 200 individuals were known in the two subpopulations of Biaoshuiyan and Shidong, respectively, and both are exposed to human disturbance. Therefore, we assess this species as a Plant Species with Extremely Small Populations (PSESP) (Yang et al. 2020).

Etymology. The specific epithet 'wutaishanensis' refers to the type locality where the new species was found, located in the Wutaishan area of Jinping Fenshuiling National Nature Reserve, Jinping County, Southeast Yunnan, China. The Chinese name is given as “五台山凤仙花”.

Additional specimens examined. Paratypes. China. Yunnan Province: Jinping County, Maandi Town, Shidong. 22\%46'19.97"N, 103²8'29.78"E, 1650 m a.s.l., 5 August 2015, Lei Cai et al., CL155 (KUN!); The same locality, 2 August 2020, R.L. Liao \& X.Y. Li, LRL202008003 (KUN!); Yunnan Province: Jinping County, Maandi Town, Biaoshuiyan, 2243'56.61"N, 10330'36.58"E, 1311 m a.s.l., 2 August 2020, R.L. Liao \& X.Y. Li, LRL202008001 (KUN!)

Discussion. The new species is most similar to Impatiens parvisepala in its racemose inflorescence, its yellow flowers with four lateral sepals. However, I. wutaishanensis is usually a shorter plant and its petiolate leaf blades are smaller and elliptic, lanceolate, or lanceolate-oblong. Its nectar spur is slightly incurved or narrowing to an incurved spur, and each inflorescence may have up to 22 flowers (Figs 1,2). In contrast, the plants of $I$. parvisepala are taller, the sessile or subsessile leaf blades are larger and obovate or obovate-lanceolate, the spur is nearly straight and the number of flowers per 


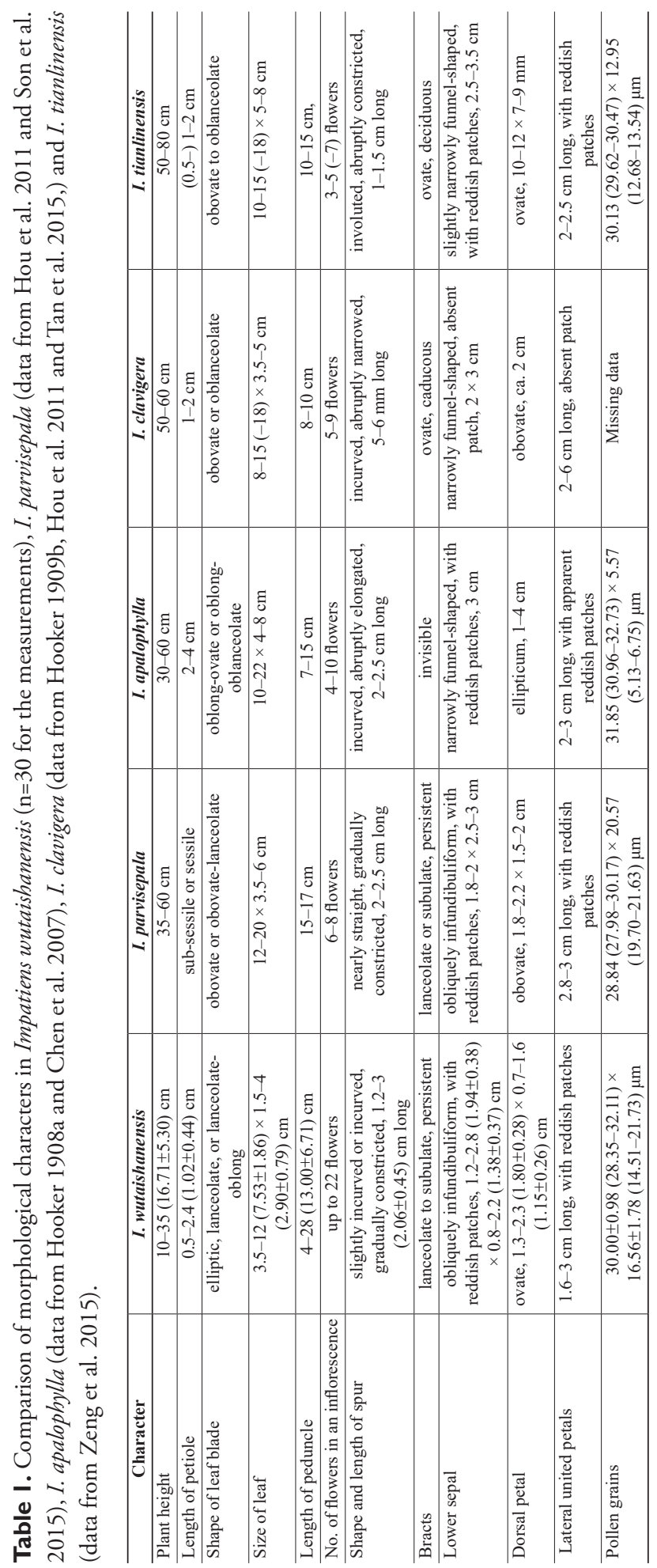


inflorescence is 6-8 (Hou et al. 2011; Son et al. 2015). The distribution of these two species is geographically isolated from each other: Impatiens wutaishanensis, is confined to Southeast Yunnan Province with two subpopulations, where the I. parvisepala is recorded in western Guangxi and northern Vietnam (Fig. 4).

In order to illustrate the morphological circumscription of the new species, we compare the new species with four species with similar morphological characters in Table 1: Impatiens apalophylla Hook. f. (1908:243), I. clavigera Hook. f. (1908:2863), I. parvisepala and I. tianlinensis S.X. Yu \& L.J. Zhang (2015: 253) (Zeng et al. 2015).

\section{Acknowledgements}

The authors are grateful to Ms. Rongmei Zhang for her beautiful drawings. We also thank Shiwei Guo, Xianyao Li and Zongli Liang for their help in collecting specimens, and Zhijia Gu for the help in cryo-SEM. Special thanks are also given to Dr. Shengxiang Yu for his assistance on species identification and providing valuable suggestions. Also, we would like to thank the anonymous reviewer for the kindly edited assistance. This work was supported by the National Science \& Technology Basic Resources Investigation Program of China: Survey and Germplasm Conservation of Plant Species with Extremely Small Population in South-west China (2017FY100100), and the Yunnan Science and Technology Innovation Team Program (2019HC015).

\section{References}

Cai XZ, Hu GW, Cong YY (2015) Impatiens xanthinoides (Balsaminaceae), a new species from Yunnan, China. Phytotaxa 227(3): 261-267. https://doi.org/10.11646/phytotaxa.227.3.5 Chen YL (2001) Balsaminaceae. In: Chen YL (Ed.) Flora Reipublicae Popularis Sinica (Vol. 47(2)), Sapindales. Science Press, Beijing, 220 pp.

Chen YL, Akiyama S, Ohba H (2007) Balsaminaceae. In: Wu ZY, Raven PH, Hong DY (Eds) Flora of China (Vol. 12). Science Press, Beijing \& Missouri Botanical Garden Press, St. Louis, 43-113.

Chinh VT, Huong NTT, Quang BH, Suksathan P (2015) A new record of Impatiens kamtilongensis Toppin (Balsaminaceae) for Vietnam Flora. Tap Chi Sinh Hoc 37(3): 332-335. https://doi.org/10.15625/0866-7160/v37n3.6967

Ding B, Gadagkar SR, Wang JC, Zhang M, Guo H, Yu SX (2016) Impatiens wawuensis (Balsaminaceae): A new species from Sichuan, China. Phytotaxa 273(4): 293-298. https://doi. org/10.11646/phytotaxa.273.4.5

Fischer E (2004) Balsaminaceae. In: Kubitzki K (Ed.) The Families and Genera of Vascular Plants (Vol. 6). Springer-Verlag Berlin, Heidelberg, New York, 20-25. https://doi. org/10.1007/978-3-662-07257-8_4

Grey-Wilson C (1980) Impatiens of Africa. CRC Press, Rotterdam, 235 pp. 
Guo H, Zhang CF, Zhang LJ, Yu SX (2016) Impatiens guiqingensis (Balsaminaceae), a new species from Gansu, China. Phytotaxa 247(3): 229-233. https://doi.org/10.11646/phytotaxa.247.3.6

Hooker JD (1908a) Les Especes Du Genre “Impatiens” dans l'Herbier du Museum de Paris. Nouvelles Archives du Museum d'Histoire Naturelle, Paris, ser. 4, 10: 233-272.

Hooker JD (1908b) Hooker's Icons Plantarum. Dulau \& Co., Ltd. London, 2863 pp.

Hou YT, Zhou XR, Yu SX (2011) Impatiens parvisepala (Balsaminaceae), a new species from Guangxi, China. Annales Botanici Fennici 48(1): 57-62. https://doi. org/10.5735/085.048.0108

IUCN (2019) Guidelines for Using the IUCN Red List Categories and Criteria. Version 14. Prepared by the Standards and Petitions Subcommittee. http://www.iucnredlist.org/documents/RedListGuidelines.pdf

Janssens S, Wilson YS, Yuan YM, Nagels A, Smets EF, Huysmans S (2012) A total evidence approach using palynological characters to infer the complex evolutionary history of the Asian Impatiens (Balsaminaceae). Taxon 61(2): 355-367. https://doi.org/10.1002/tax.612007

Linnaeus C (1753) Species Plantarum 2. Laurentius salvius, Stockholm, 937 pp.

Lu YQ (1991) Pollen morphology of Impatiens L. (Balsaminaceae) and its taxonomic implications. Acta Phytotaxonomica Sinica 29(4): 352-357.

Lu ZC, Pan B, Huang FZ, Liu Y (2020) Impatiens gongchengensis (Balsaminaceae), a new species from Guangxi, Southern China. Taiwania 65(1): 1-4. https://doi.org/10.6165/ tai.2020.65.1

Peng YC, Peng S, Yang N, Xu ZG, Cong YY (2020) Impatiens bomiensis (Balsaminaceae), a new species from Xizang, China. Nordic Journal of Botany 38(8): e02761. https://doi. org/10.1111/njb.02761

Shui YM, Janssens S, Huang SH, Chen WH, Yang ZG (2011) Three new species of Impatiens L. from China and Vietnam: Preparation of flowers and morphology of pollen and seeds. Systematic Botany 36(2): 428-439. https://doi.org/10.1600/036364411X569615

Son HT, Bon Tn, Hung NQ, Vinh PV, Anh TV (2015) Impatiens parvisepala (Balsaminaceae): a newly recorded from Vietnam. Vietnam Journal of Forest Science 4: 4018-4020. http:// vafs.gov.vn/

Song Y, Yuan YM, Kupfer P (2003) Chromosomal evolution in Balsaminaceae, with cytological observations on 45 species from Southeast Asia. Caryologia 56(4): 463-481. https://doi.or g/10.1080/00087114.2003.10589359

Tan YH, Liu YN, Jiang H, Zhu XX, Zhang W, Yu SX (2015) Impatiens pandurata (Balsaminaceae), a new species from Yunnan, China. Botanical Studies 56: 29. https://doi.org/10.1186/ s40529-015-0108-4

Xia CY, Gadagkar SR, Li J, Deng HP, Yu SX (2019a) Impatiens damingensis (Balsaminaceae), a new species from Guangxi, China. Phytotaxa 399(3): 239-247. https://doi.org/10.11646/ phytotaxa.399.3.6

Xia CY, Sudhindra RG, Zhao XL, Do TV, Zhu XY, Qin Y, Yu SX (2019b) Impatiens maculifera sp. nov. (Balsaminaceae) Yunnan, China. Nordic Journal of Botany 37(8): e02422. https:// doi.org/10.1111/njb.02422 
Yang J, Cai L, Liu DT, Chen G, Gratzfeld J, Sun WB (2020) China’s conservation program on Plant Species with Extremely Small Populations (PSESP): Progress and perspectives. Biological Conservation 244: e108535. https://doi.org/10.1016/j.biocon.2020.108535

Yu SX (2012) Balsaminaceae of China. Peking University Press, Beijing, 206 pp.

Yuan YM, Song Y, Geuten K, Rahelivololona E, Wohlhauser S, Fischer E, Kupfer P (2004) Phylogeny and biogeography of Balsaminaceae inferred from ITS sequences. Taxon 53(2): 391-403. https://doi.org/10.2307/4135617

Zeng L, Liu YN, Gogoi R, Zhang LJ, Yu SX (2015) Impatiens tianlinensis (Balsaminaceae), a new species from Guangxi, China. Phytotaxa 227(3): 253-260. https://doi.org/10.11646/ phytotaxa.227.3.4

Zhang LR, Zhang ZX, Meng R, Yu SX (2013) Impatiens pterocaulis sp. nov. (Balsaminaceae) from Guangxi, China. Nordic Journal of Botany 32(1): 64-69. https://doi.org/10.1111/ j.1756-1051.2012.01743.x 